\title{
Incorporation of Leguminous Cover Crops in Smallholder Cassava-Based Production System in Western Tanzania
}

\author{
Peter Z. Matata ${ }^{1}$, Alexandre M. A. Passos ${ }^{2 *}$, Leah W. Masolwa1, Alaerto L. Marcolan ${ }^{3}$, \\ Rodrigo da S. Ribeiro ${ }^{4}$
}

${ }^{1}$ Tumbi Agricultural Research Institute, Tabora, Tanzania

${ }^{2}$ Embrapa Maize and Sorghum, Sete Lagoas, Brazil

${ }^{3}$ Embrapa Rondonia, Porto Velho, Brazil

${ }^{4}$ Federal University of Rondonia, Rolim de Moura, Brazil

Email: *alexandre.abdao@embrapa.br

How to cite this paper: Matata, P.Z., Passos, A.M.A., Masolwa, L.W., Marcolan, A.L. and Ribeiro, R. da S. (2017) Incorporation of Leguminous Cover Crops in Smallholder Cassava-Based Production System in Western Tanzania. American Journal of Plant Sciences, 8, 3490-3501. https://doi.org/10.4236/ajps.2017.813235

Received: November 23, 2017

Accepted: December 24, 2017

Published: December 27, 2017

Copyright $\odot 2017$ by authors and Scientific Research Publishing Inc. This work is licensed under the Creative Commons Attribution International License (CC BY 4.0).

http://creativecommons.org/licenses/by/4.0/

\section{Open Access}

\begin{abstract}
Small-scale crop production in many parts of Tanzania is constrained by many problems among which soil fertility degradation is a major problem. Over $80 \%$ of cassava (Manihot esculenta) production in Tanzania is done by the small-scale farmers who continuously cultivate their fields, but use limited inputs to restore depleted plant nutrients. The objective of this study was to examine the best legume species that could be incorporated in cassava ( $\mathrm{Ma}$ nihot esculenta) production systems under farmers' conditions and result in increase in soil fertility and crop yields. Mucuna pruriens and Canavalia ensiformis were either incorporated with cassava (Manihot esculenta) or planted as sole crop in rotation with cassava. Mucuna pruriens and Canavalia ensiformis were found to produce almost similar amount of biomass. The two legumes, however, produced higher biomass in rotation than intercropping system. The amount of biomass produced by Mucuna pruriens and Canavalia ensiformis in rotation system was $6.28 \mathrm{t} \cdot \mathrm{ha}^{-1}$ and $5.31 \mathrm{t} \cdot \mathrm{ha}^{-1}$, respectively. The Mucuna use represents an input of nitrogen into the soil which simulates a

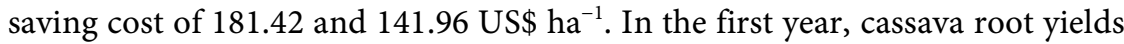
were significantly increased $(p<0.05)$ over control (continuous sole cassava) $\left(1.44 \mathrm{t}^{-\mathrm{ha}^{-1}}\right)$ by the use of intercropping of cassava (Manihot esculenta) with Mucuna pruriens $\left(2.41 \mathrm{t} \cdot \mathrm{ha}^{-1}\right)$ and or Canavalia ensiformis $\left(2.25 \mathrm{t} \cdot \mathrm{ha}^{-1}\right)$. Intercropping and rotation of cassava with legumes increase cassava yield and represent a sustainable alternative to reduce the farms' dependence on external inputs and to enhance inherent soil fertility.
\end{abstract}




\section{Keywords}

Mucuna pruriens, Canavalia ensiformis, Intercropping, Rotation, Climate Change

\section{Introduction}

Low soil fertility is widely recognized as a major obstacle to improving agricultural productivity in sub-Saharan Africa [1]. Given the strong linkage between soil fertility and food insecurity, addressing the decline in soil fertility remains an important challenge for those faced with formulating Africa's development policy agenda [2]. The rapid growth of population in developing countries and the intensive cultivation of agricultural land are causing widespread soil degradation.

The low and declining productivity of many tropical soils are the major constraints limiting the realization of improved genetic potential of crops that is now available [3]. Depletion of soil fertility contributes to low per capital food production and is one factor of poverty in sub-Saharan Africa. The need to take appropriate measures to avoid this decline in soil productivity is urgent as the rate of deterioration is on increase and if not checked will have serious implications for future food demands of the increasing human population [3].

One alternative to restore soil fertility is the use of high-soluble fertilizers; however, the ratio of the price of inorganic fertilizers is unfavorable to most of the smallholder farmers because of the high price. These situations create food insecurity and low income to resource poor farmers. Other alternative is to intercrop or rotate crops with legumes as a low-cost approach to adding nitrogen in the soil [4].

In Southern Africa, increased yield of subsequent cereal crops after leguminous plants has been demonstrated [5]. Brazilian experiences have shown positive effects using legumes as Canavalia ensiformis, Chamaecrista rotundifolia, Acacia mangium, Inga edulis and Cajanus cajan for soil reclamation [6] [7] [8], improving maize [9] and cassava (Manihot esculenta) productivity [10]. However, farmers grow crops solely or as intercrop. There are many crop combinations, and the combinations range from simple to complex (especially near homesteads). The predominant ones are simple and usually combine cereals with legumes. Whatever the combination, intercropping is an intensive and sustainable land use system evolved over the years through the farmers experiments [11]. To further mention, more than $80 \%$ of farmers in Africa practice intercropping. Biomass using fertilizer-shrub species is shown as a sustainable means for maintaining nutrient balances in maize and vegetables-based production systems. The leaf materials are able to supply Nitrogen to the soil [12]. There is therefore increased dependence on the use of organic waste such as Farmyard Manure (FYM), compost and crop residues. 
These are highly valued because of their contribution to soil productivity.

The relationship between Soil Organic Matter (SOM) and productivity is ascribed to the role of SOM in supplying plant nutrients, enhancing water holding capacity, improving soil aggregation and hence water holding capacity, improving soil $\mathrm{pH}$, supporting soil biological activity, consequently giving higher crop yield compared to treatments from which the crop residue had been removed [1]. Research efforts at Tanzania have been focused in some regions on alternatives, cost effective and locally available nutrient sources that can improve crop yields through improved soil fertility and water conservation. Green manure from Mucuna and lab and $\mathrm{N}$-fixing legumes are some of the important organic nutrient sources-poor farmers could use for soil fertility replacement [13] [14].

In some villages of western Tanzania, most farmers use neither fertilizers nor farm yard manure [15]. Green manure, farm yard manure and $\mathrm{N}$-fixing legumes are some of the important organic nutrient sources that resource-poor farmers could use for soil fertility replenishment [16]. The growing of leguminous plants and shrubs is increasingly being recommended and adopted for integration in smallholder farming systems as a source of nutrients (green manure and mulch) for crop production and fodder for livestock in the dry season. Preliminary studies to screen some leguminous pastures and shrubs for use in soil nitrogen replenishment in Kenya and Tanzania [17] [18] have reported positive results from use of Mucuna pruriens and Centrosema pubescences in cassava-legume cropping systems. Both species produce a large biomass with high concentration of Nitrogen [19].

Although many studies emphasize the use of legumes, little has been reported in Tanzania on the use of Mucuna pruriens and Canavalia ensiformis for improving soil fertility of small scale farmers. This paper aimed to evaluate the influence of Mucuna pruriens and Canavalia ensiformis to improve soil fertility and cassava root yield in Western Tanzania.

\section{Methods and Materials}

Kigoma region is located on shores of Lake Tanganyika at the North-West corner of Tanzania. The region is situated between longitude 29.5 and 31.5 East and latitude 3.5 and 6.5 South of the equator. The region is characterized by a unimodal rainfall regime with annual total rainfall between $500-1500 \mathrm{~mm}$. The region is divided into four agroeconomical zones, namely the lake shore zone, the miombo forest zone, the intermediate zone and the highlands zones [20]. The main economic activity in Kigoma is farming cereal crop such as maize, beans and cassava. Besides that sale of surplus harvests, farmers earn incomes from cash crops such as oilpalm.

The experiment was carried out in Kasulu district in Kigoma Region in areas low in $\mathrm{N}$ and P. The study involved Fifty (50) farmers in the district. The farmers were randomly selected at the region. Rainfall and potential evapotranpiration 
were measured by sattelite imagens gathered data of two years (2015 and 2016) in the experimental fields region [21] (Figure 1).

Before initiation of the trials, composite soil samples were collected from each farmer's field for initial fertility determination using soil auger at 0 - 15, $15-30$ $\mathrm{cm}$ depth from 4 randomly selected spots within the plots. The samples were analysed for $\mathrm{pH}$, organic carbon, available phosphorus and exchangeable cations ( $\mathrm{Na}, \mathrm{K}, \mathrm{Ca}$ and $\mathrm{Mg}$ ) and total nitrogen (Table 1).

Organic carbon was determined using the Walkey and Black wet oxidation method using concentrated sulphuric acid and aqueous potassium dichromate [22]. Electrical conductivity and $\mathrm{pH}$ were determined in 1:2.5 ratios: distilled water paste [14] using electrical conductivity and $\mathrm{pH}$ meter respectively. Total Nitrogen was analysed using the semi-micro Kjedahl procedure after digesting samples in concentrated sulphuric acid and hydrogen peroxide as an oxidizing agent.

The trial design was randomized complete randomized block (RCBD) with individual farmer field plots as replicates. Plot size was $10 \times 10 \mathrm{~m}$ and the net plot $8 \times 8 \mathrm{~m}$ separated by $1 \mathrm{~m}$ distance, in which 10 rows of cassava were planted at a spacing of $1 \times 1 \mathrm{~m}$, within and between rows spacing respectively.

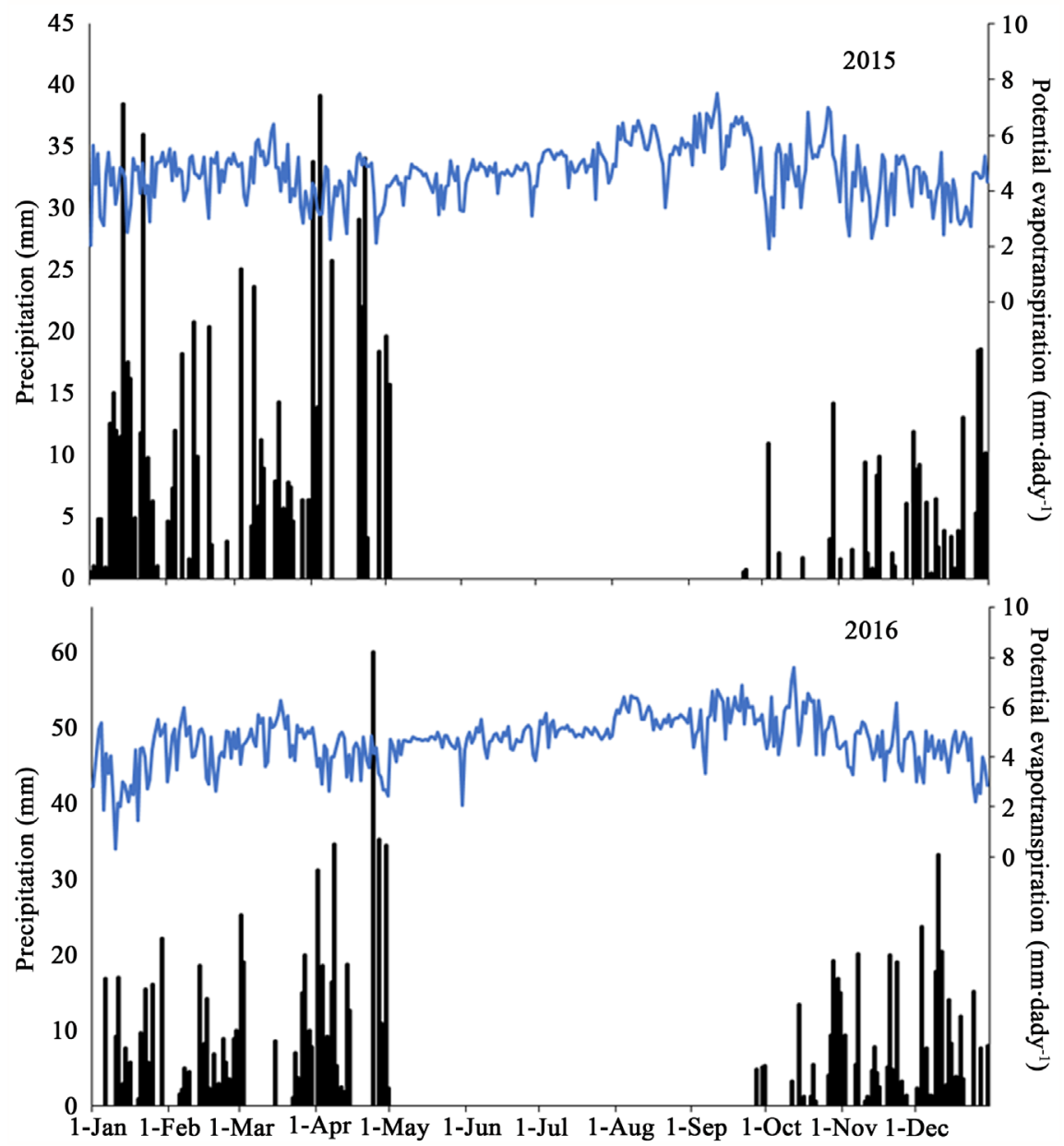

Figure 1. Precipitation in the experimental period in the region. 
Table 1. Soil physical and chemical properties before planting of cover crops and cassava in February 2015.

\begin{tabular}{ccc}
\hline Properties & Soil depth $(\mathrm{cm})$ & Medium value \\
\hline Organic C $\left(\mathrm{g} \cdot \mathrm{kg}^{-1}\right)$ & 0 to 15 & 3.21 \\
Total $\mathrm{N}\left(\mathrm{g} \cdot \mathrm{kg}^{-1}\right)$ & 0 to 15 & 0.29 \\
Available P $\left(\mathrm{mg} \cdot \mathrm{kg}^{-1}\right)$ & 0 to 15 & 6.09 \\
Exchangeable Ca $\left(\mathrm{cmol} \cdot \mathrm{kg}^{-1}\right)$ & 0 to 15 & 4.05 \\
Exchangeable $\mathrm{Mg}\left(\mathrm{cmol} \cdot \mathrm{kg}^{-1}\right)$ & 0 to 15 & 1.25 \\
Exchangeable $\mathrm{K}\left(\mathrm{cmol} \cdot \mathrm{kg}^{-1}\right)$ & 0 to 15 & 0.15 \\
pH (in water $1: 2.5)$ & 0 to 15 & 6.30 \\
& 15 to 30 & 5.88 \\
Bulk density $\left(\mathrm{g} \cdot \mathrm{cm}^{-3}\right)$ & 0 to 15 & 1.151 \\
& 15 to 30 & 11.358 \\
Sand (\%) & 0 to 15 & 57.8 \\
Silt (\%) & & 14.2 \\
Clay (\%) & & 38.5 \\
\hline
\end{tabular}

Treatments were as followed: 1) Cassava without legumes (Control); 2) Cassava with recommended mineral-fertilizer applied at the time of planting $(50 \mathrm{~kg}$ $\mathrm{N} \mathrm{ha}^{-1}$ ) applied to cassava in both seasons; 3) Mucuna pruriens sole crop (rotation system); 4) Cassava intercropped with Mucuna pruriens planted two weeks after planting cassava; 5) Canavalia ensiformis sole crop (rotation system); 6) Cassava intercropped with Canavalia ensiformis planted two weeks after planting cassava. The used cassava variety from IITA was Mkombozi with 125 days to maturity. Sole cassava was grown in the first season 2015 and 2016 in order to test the residual value of Mucuna pruriens and Canavalia ensiformis.

Phosphorus was applied to all treatments at a rate of $45 \mathrm{~kg} \mathrm{P}_{2} \mathrm{O}_{5} \mathrm{ha}^{-1}$ to one season. Legumes-Mucuna and Canavalia ensiformis intercropped in between cassava row $30 \mathrm{~cm}$ apart, while Mucuna and Canavalia ensiformis sole crop-75 $\mathrm{cm}$ between rows, $0.3 \mathrm{~m}$ within rows. At harvesting, all cassava in the eight middle rows was harvested. From the middle eight rows, root of the cassava plants were harvested and weighted. Subsamples were taken to laboratory to oven dry to $65^{\circ} \mathrm{C}$ for estimation of harvested dry weight.

Cover plants samples were ground to $0.5 \mathrm{~mm}$ and digested according to [23] in order to determine the nutrients accumulation on shoot. Total $\mathrm{N}$ was determined with ammonium sensitive electrode. $\mathrm{Ca}, \mathrm{Mg}$, and $\mathrm{K}$ were analyzed by atomic absorption spectrophotometer. Total $\mathrm{P}$ was determined by the malachite green colorimetric procedure [24]. A corresponding value cost of the nitrogen accumulated by the gree manure plants shoot, using the urea chemical fertilizer, was calculed to each cropping system. The local price of US500 per tonne of urea (45\% nitrogen concentration) was used. 
Mean cassava yield data of two years (2015 and 2016) were used in the partial budget analysis [25]. The gross benefit was calculated as average adjusted cassava yield ( $\mathrm{kg} \cdot \mathrm{ha}^{-1} \times$ field price) that farmers receive for the sale of the crop. Total variable cost was calculated as the sum of all cost that is variable or specific to a treatment against control.

$$
\mathrm{TVC}=a+b+c+d
$$

where:

TVC: Total variable cost $\left(\right.$ US $\left.\$ \mathrm{ha}^{-1}\right)$;

a: cassava cuttings (US\$ ha $\left.{ }^{-1}\right)$;

$b$ : legume seeds (US $\left.\$ \mathrm{ha}^{-1}\right)$;

c. fertilizes (US\$ ha $\left.{ }^{-1}\right)$;

d: labour $\left(\mathrm{US} \$ \mathrm{ha}^{-1}\right)$.

Net benefit was calculated by subtracting total variable cost from gross benefit.

$$
\mathrm{NB}=\mathrm{GB}-\mathrm{TVC}
$$

where:

NB: net benefit (US\$ ha $\left.{ }^{-1}\right)$;

GB: gross benefit (US $\$ \mathrm{ha}^{-1}$ );

TVC: total variable cost (US\$ ha $\left.{ }^{-1}\right)$.

The marginal rate of return (MRR) was calculated as the ratio of differences between net benefits to successive treatments to the difference between total variable costs of successive treatments.

$$
\mathrm{MRR}=\frac{\mathrm{RL}}{\mathrm{CT} v}
$$

where:

MRR: marginal rate of return;

NB: net benefit;

TVC: Total variable cost.

Data from the trials were organized and analysed using the GENSTAT statistical programme. Significant differences at $p<0.05$ are indicated by DMRT. Production costs for economic analysis were analysed through partial budget analysis.

\section{Results and Discussion}

Mucuna and Canavalia ensiformis were found to produce almost similar amount of biomass. The two legumes, however, produced higher biomass in rotation than intercropping system (Table 2). The amount of biomass produced by $\mathrm{Mu}-$ cuna and Canavalia ensiformis in rotation system was $6.28 \mathrm{t} \cdot \mathrm{ha}^{-1}$ and $5.31 \mathrm{t} \cdot \mathrm{ha}^{-1}$, respectively. In intercropping system, amount of biomass produced by the two legumes was 5.31 and $3.82 \mathrm{t} \cdot \mathrm{ha}^{-1}$, respectively. The lower biomass production in intercropping system was probably attributed to the shading effect from the cassava crop. Through observation, the weed density was slightly lower in Mucuna pruriens plots than in Canavalia ensiformis, but all were far less than in control. 
Table 2. Mean dry matter (biomass) yield, Nitrogen content, Nitrogen yield and simulated cost of replacement by urea of cover crops during the 2015 and 2016 growth seasons.

\begin{tabular}{ccccc}
\hline Cropping systems & $\begin{array}{c}\text { Biomass } \\
\left(\mathrm{t} \cdot \mathrm{ha}^{-1}\right)\end{array}$ & $\begin{array}{c}\text { Nitrogen content } \\
(\%)\end{array}$ & $\begin{array}{c}\text { Nitrogen } \\
\left(\mathrm{kg} \cdot \mathrm{ha}^{-1}\right)\end{array}$ & $\begin{array}{c}\text { Cost saving } \\
\left(\mathrm{US} \$ \mathrm{ha}^{-1}\right)\end{array}$ \\
\hline Mucuna cassava rotation & 6.28 & 2.60 & 163.28 & 181.42 \\
Cassava Mucuna intercropping & 5.05 & 2.53 & 127.77 & 141.96 \\
Canavalia cassava rotation & 5.31 & 2.40 & 127.44 & 141.60 \\
Cassava Canavalia intercropping & 3.82 & 2.34 & 89.39 & 99.32 \\
\hline
\end{tabular}

Effect of rotation and intercropping of cassava with Mucuna and Canavalia ensiformis on cassava yield. Legume incorporation and $\mathrm{N}$ fertilizer significantly affected cassava yield in the two seasons 2015 and 2016 seasons (Table 3). Cassava yield was significantly higher with incorporation of legumes than the control for the two seasons. Rotation and intercropping of cassava with Mucuna and or Canavalia ensiformis increased cassava yield significantly over control (Continuous sole cassava) during the second season (Table 3). Mean separation of the responses showed that more cassava yield was obtained under rotation system of the legumes. The difference recorded between legumes could be attributed to their quality and quantity of biomass produced [26].

In general, on average they increased cassava yield over the control treatment by $118 \%$ and $56 \%$ under rotation and intercropping systems respectively. Jarvis et.al, 2012, reported that cassava yield was more than doubled by incorporation of three month old Mucuna and Crotalaria grown in alluvial soil on the island of Java, Indonesia. These results showed that the two legumes did not differ significantly on their effects on cassava yield under the different cropping systems, meaning that the two legumes have almost equal potential as source of nitrogen for soil fertility replenishment. The higher effect of the legumes on cassava yield observed under rotation over intercropping system could be due to a higher biomass produced and incorporated into the soil.

Comparison of the mineral fertilizer treatment $\left(50 \mathrm{~kg} \mathrm{~N} \mathrm{ha}^{-1}\right)$ with two legumes under the two cropping systems showed that mineral nitrogen fertilizer was not statically different from the two legumes under the two cropping systems. However, the mean cassava yield of the mineral fertilizer was slightly lower but higher than the mean cassava yield under rotation and intercropping systems, respectively. The inferior effect of the mineral nitrogen fertilizer over the green manure under rotation system could probably be attributed to excessive leaching effect as a result of high rainfall during the second season. Increase in cassava yield with the incorporation of forage legumes had been reported by several researchers [27].

In the present study we have shown that nitrogen content of the two legumes was high (Mucuna 2.60\% and Canavalia 2.40\%) and there was no much difference in nitrogen content of the biomass harvested from the two different cropping systems (Table 4). The high nitrogen content of the two legumes indicated 
Table 3. Effect of legume incorporation after two years of growth and $\mathrm{N}$ fertilizer on cassava yield.

\begin{tabular}{cccc}
\hline & \multicolumn{2}{c}{ Cassava yield $\left(\mathrm{t} \cdot \mathrm{ha}^{-1}\right)$} & \\
\cline { 2 - 3 } Treatment & 2015 & 2016 & Yield increase (\%) \\
Control & $1.44 \mathrm{c}$ & $2.00 \mathrm{c}$ & 0 \\
Cassava $+50 \mathrm{~kg} \mathrm{~N} \mathrm{ha}^{-1}$ & $2.76 \mathrm{ab}$ & $2.83 \mathrm{~b}$ & 118 \\
Mucuna rotation & $3.14 \mathrm{a}$ & $3.79 \mathrm{a}$ & 62 \\
Cassava Mucuna intercropping & $2.41 \mathrm{~b}$ & $2.80 \mathrm{~b}$ & 120 \\
Canavalia rotation & $3.03 \mathrm{ab}$ & $3.28 \mathrm{ab}$ & 56 \\
Cassava Canavalia intercropping & $2.25 \mathrm{~b}$ & $2.39 \mathrm{~b}$ & \\
Mean & 2.51 & 2.85 & 8.4 \\
\hline
\end{tabular}

Means followed by the same letter are not significantly different according to DMRT $(P>0.05)$.

Table 4. Nutrient uptake $\left(\mathrm{kg} \cdot \mathrm{ha}^{-1}\right)$ of cassava planted after Mucuna pruriens and Canavalia ensiformis and control in 2015 and 2016.

\begin{tabular}{ccccccccccc}
\hline & \multicolumn{2}{c}{ Nitrogen } & \multicolumn{2}{c}{ Phosphorus } & Potassium & \multicolumn{2}{c}{ Calcium } & \multicolumn{2}{c}{ Magnesium } \\
\cline { 2 - 10 } Cropping systems & 2015 & 2016 & 2015 & 2016 & 2015 & 2016 & 2015 & 2016 & 2015 & 2016 \\
\hline $\begin{array}{c}\text { Mucuna pruriens } \\
\text { Canavalia }\end{array}$ & $102.4 \mathrm{a}$ & $63.2 \mathrm{a}$ & $18.6 \mathrm{ab}$ & $13.2 \mathrm{ab}$ & $115.0 \mathrm{ab}$ & $68.2 \mathrm{a}$ & $22.2 \mathrm{a}$ & $13.0 \mathrm{bc}$ & $9.7 \mathrm{ab}$ & $9.7 \mathrm{ab}$ \\
$\begin{array}{c}\text { Control } \\
\text { (no fertilizers) }\end{array}$ & $57.8 \mathrm{~b}$ & $45.6 \mathrm{~b}$ & $14.7 \mathrm{bc}$ & $11.9 \mathrm{ab}$ & $86.1 \mathrm{bc}$ & $50.0 \mathrm{bc}$ & $14.4 \mathrm{bc}$ & $11.0 \mathrm{c}$ & $8.1 \mathrm{bc}$ & $8.1 \mathrm{bc}$ \\
\hline
\end{tabular}

Means followed by the same letter are not significantly different according to DMRT $(P>0.05)$.

that they can be used as source of nitrogen for soil fertility replenishment [28] have also reported similar levels of nitrogen content from the two legumes.

The total $\mathrm{N}$ uptake of cassava was quite different between treatments. More was taken up in Mucuna pruriens followed by Canavalia ensiformis than after control in both years (Table 4). The same pattern was found for $\mathrm{K}, \mathrm{Ca}$, and $\mathrm{Mg}$. The P uptake of cassava after Mucuna pruriens was higher than after Canavalia ensiformis and control. The $\mathrm{N}$ amounts taken up were consistently lower in 2016 than 2015. The uptake of other nutrients did not differ between years. [29] found an equivalent of $119 \mathrm{~kg} \cdot \mathrm{ha}^{-1}$ for Mucuna spp. in the Rwanda Highlands leading to cassava yield of $3.13 \mathrm{~kg} \cdot \mathrm{ha}^{-1}$. Mucuna produced $22.3 \mathrm{~kg} \cdot \mathrm{ha}^{-1}$ of fresh matter biomass in their trials.

Economic analysis (Table 5) following partial budget analysis showed that intercropping cassava with Mucuna pruriens and Canavalia ensiformis gave higher net benefit than when the two legumes are grown under rotation system. In rotation system cassava crop is forgone in the first season and the only benefit that the farmer could get is improved soil fertility.

Comparison of the mineral nitrogen treatment with the two legumes as a source of nitrogen indicated that a higher net benefit was obtained from use of 
Table 5. Total variable cost (TVC), net benefit (NB) and marginal rate of return (MRR) of cassava cropping systems ${ }^{1}$.

\begin{tabular}{|c|c|c|c|}
\hline \multirow{2}{*}{ Cropping systems } & TVC $^{2}$ & $\mathrm{NB}^{3}$ & \multirow{2}{*}{$\mathrm{MRR}^{4}$} \\
\hline & US\$ ha $\mathrm{h}^{-1}$ & US\$ ha ${ }^{-1}$ & \\
\hline Control & 38.83 & 69.35 & 1.79 \\
\hline Mucuna-Cassava rotation & 29.69 & 64.59 & 2.18 \\
\hline Cassava-Mucuna intercropping & 30.84 & 107.31 & 3.48 \\
\hline Canavalia-rotation & 29.69 & 65.33 & 2.20 \\
\hline Cassava-Canavalia ensiformis intercropping & 30.84 & 109.50 & 3.55 \\
\hline
\end{tabular}

the two legumes than mineral fertilizer. Reasons for the lower net benefit recorded from the mineral $\mathrm{N}$ treatment versus the legumes could be attributed to high price ratio of mineral fertilizers to price ratio of cassava crop. Price of mineral fertilizers has being going-up over the years whereas that cassava remained constant or even went down.

However, farmer's evaluation of the treatments showed that Mucuna was chosen as first priority for soil fertility and cassava yield improvement. However, its habit of coiling on cassava, made Mucuna suitable in rotation system. Canavalia ensiformis was chosen as best-bet because it can be used both in rotation as well as in intercropping system as it does not coil on cassava. Mucuna was considered to be equally useful as Canavalia ensiformis in terms of cassava yield improvement, however, its habit of coiling on cassava and strangle it, made to be suitable only in rotation systems. But acceptability of the farmers to use the two legumes for soil fertility improvement under rotation system was low because the legumes do not have other economic benefit(s) other than soil fertility improvement.

\section{Conclusions}

Use of nitrogen fertilizers in the study area is important for improving cassava yields. Farmers who can afford to apply mineral nitrogen fertilizers $\left(50 \mathrm{~kg} \cdot \mathrm{ha}^{-1}\right)$ or above can expect cassava yield improvement of about $88 \%$ than farmers who do not use mineral fertilizer. However, farmers that can use Mucuna and Canavalia ensiformis legumes as source of nitrogen with cassava can get higher cassava about $118 \%$ than those farmers who do not use Nitrogen fertilizers. Also, farmers who could intercrop cassava with either of the two legumes can expect cassava yields of about $56 \%$ than those farmers who do not use mineral nitrogen fertilizers.

Based on economic analysis, higher net benefit was obtained from intercropping than rotation system either of the two legumes. Rotation system had lower net benefits because of cassava crop that was forgone during the first season, thus making net return for this treatment low.

It was concluded that both Mucuna and Canavalia ensiformis legumes have 
high potential as organic nitrogen source for soil fertility restoration, and hence cassava yield improvement.

More studies are needed in future to study on; amount of nitrogen contributes to the soil by the two legumes through biological fixation and effect of the two legumes as cover crop for soil moisture conservation and weed suppression.

\section{Acknowledgements}

We would like to express our sincere thanks first to the Market Place Initiative for financial support for the two years of implementation of the project. Also we would like to extend our sincere thanks to the Director, ARI-Tumbi for assistance and material support during the implementation of the project, also wish to thank Daldo Kasulu and his staff, particularly Mr. Mathias and Odilo for data recording in the farmers' field.

\section{References}

[1] Sanchez, P.A. (2002) Soil Fertility and Hunger in Africa. Science, 295, 2019-2020. https://doi.org/10.1126/science.1065256

[2] Kavia, F.Y., Mushongi, C.C. and Sonda, G.B. (2007) Factors Affecting Adoption of Cassava Varieties: A Case of Cassava Mosaic Disease Tolerant Varieties in Lake Zone Regions-Tanzania. In: 8th African Crop Science Society Conference, El Minia, 27-31 October 2007, 1875-1878. http://www.acss2007.org

[3] Sopheap, U., Patanothai, A. and Aye, T.M. (2012) Unveiling Constraints to Cassava Production in Cambodia: An Analysis from Farmers' Yield Variations. International Journal of Plant Production, 6, 409-428.

[4] Wortmann, C.S., Lunze, L., Ochwoh, V.A. and Lynch, J. (1995) Bean Improvement for Low Fertility Soils in Africa. African Crop Science Journal, 3.

[5] Mafongoya, P.L., Bationo, A., Kihara, J. and Waswa, B.S. (2007) Appropriate Technologies to Replenish Soil Fertility in Southern Africa. Advances in Integrated Soil Fertility Management in Sub-Saharan Africa: Challenges and Opportunities, Springer, Dordrecht, 29-43.

[6] Lopes OMN (2000) GUANDU: Leguminosa Para Controle de Mato, Adubação Verde Do Solo e Alimentação Animal. Belém: Embrapa-Belém: Embrapa Amazônia Oriental. (Tecnics Recomendations, 11).

[7] de Aragão, D.V., de Carvalho, C.J.R., Kato, O.R., de Araújo, C.M., dos Santos, M.T.P. and Mourão Júnior, M. (2012) Avaliação de Indicadores de Qualidade Do Solo Sob Alternativas de Recuperação Do Solo No Nordeste Paraense. Acta Amazonica, 42, 11-18. https://doi.org/10.1590/S0044-59672012000100002

[8] Aker A.M., Passos, A.M.A., Costa, R.S.C., Santos, F.C., Leite, V.P.D. and Marcolan, A.L. (2017) Cover Crops on Physico-Chemical Attributes of Soil in a Short-Term Experiment in the Southwestern Amazon Region. African Journal of Agricultural Research, 12, 455-567. https://doi.org/10.5897/AJAR2017.12800

[9] Aker, A.M., Passos, A.M.A.D., Marcolan, A.L., Santos, F.C.D., Cipriani, H.N. and Vargas, L.A.D. (2016) Plantas de cobertura sobre atributos agronômicos do milho na região sudoeste da Amazônia. Revista Brasileira de Milho e Sorgo, 15, 531-542. https://doi.org/10.18512/1980-6477/rbms.v15n3p531-542

[10] de Aragão, D.V., de Carvalho, C.J.R., Kato, O.R. and Mourão Júnior, M. (2011) 
Alternativa de base ecológica para melhoria da fertilidade do solo e da produção agrícola no sistema de corte-e-trituração, no Nordeste Paraense. Cadernos de Agroecologia, 6, 1-6.

[11] Waddington, S.R., Palmer, A.F.E. and Edje, O.T. (1990) Research Methods for Cereal/Legume Intercropping in Eastern and Southern Africa. CIMMYT, Mexico, D.F. http://repository.cimmyt.org/xmlui/handle/10883/525

[12] Kuntashula, E., Mafongoya, P.L., Sileshi, G. and Lungu, S. (2004) Potential of Biomass Transfer Technologies in Sustaining Vegetable Production in the Wetlands of Eastern Zambia. Experimental Agriculture, 40, 37-51. https://doi.org/10.1017/S001447970300142X

[13] Palm, C.A. and Rowland, A.P. (1997) A Minimum Data Set for Characterization of Plant Quality for Decomposition. In: Candish, G. and Giller, K.E., Eds., Driven by Nature: Plant Litter Quality and Decomposition, CAB International, 37-392.

[14] De Souza, A., Massenburg, L., Jaiswal, D., Cheng, S., Shekar, R. and Long, S. (2016) Issue Information. New Phytologist, 213, 50-65. http://onlinelibrary.wiley.com/doi/10.1111/nph.14226/full

[15] FAOSTAT (2006) FAO Statistical Databases-Agricultural Data. http://faostat.fao.org

[16] Urassa, G.J., Tenge, A.J. and Senkero, J. (2002) Improvement of Soil Fertility and Crop Yields through Participatory Learning and Action Research in Selected Village in Muheza District. Diagnostic Survey Report (Phase 1) ISF/IPNM, ARI-Mlingano, Tanga.

[17] Mreith, F.M., Thijssen, H.J.C., Mugendi, D.N., Mwangi, J.N., O’Neill, M.K. and Nyaata, O.Z. (1994) Report of a Survey on Agroforestry Technologies Used for Fodder Production and Soil Fertility Improvement in Meru District, Kenya.

[18] Otsyina, R., Msangi, R., Gama, B., Ramadhani and Shirima, D. (1996) SADC-ICRAF Agroforestry Research Project, Tumbi, Tabora, Tanzania. Annual Report.

[19] Heichel, G.H. and Barnes, D.K. (1984) Opportunities for Meeting Crop Nitrogen Needs from Symbiotic Nitrogen Fixation [by Rhizobium-Legume]. ASA Special Publication-American Society of Agronomy (USA). http://agris.fao.org/agris-search/search.do?recordID=US8505385

[20] Trendscassava, R., Historic, P. and Africa, S. (2005) Cassava Production Trends. A Review of Cassava in Africa with Country Case Studies on Nigeria, Ghana, the United Republic of Tanzania, Uganda and Benin Proceedings of the Validation Forum on the Global Cassava Development Strategy, Vol. 2.

[21] Allen, R.G., Burnett, B., Kramber, W., Huntington, J., Kjaersgaard, J., Kilic, A., Kelly, C. and Trezza, R. (2013) Automated Calibration of the METRIC-Landsat Evapotranspiration Process. JAWRA Journal of the American Water Resources Association, 49, 563-576. https://doi.org/10.1111/jawr.12056

[22] Okalebo, J.R., Gathua, K.W. and Woomer, P.L. (1993) Laboratory Methods of Soil and Plant Analysis: A Working Manual. ROSTA, Nairobi, Tropical Soil Biology and Fertility Programme, $88 \mathrm{p}$.

[23] Novozamsky, I., Houba, V.J.G., van Eck, R. and van Vark, W. (1983) A Novel Digestion Technique for Multi-Element Plant Analysis. Communications in Soil Science and Plant Analysis, 14, 239-248. https://doi.org/10.1080/00103628309367359

[24] Motomizu, S., Oshima, M. and Hirashima, A. (1988) Spectrophotometric Determination of Phosphorus in River Water Based on the Reaction of Vanadomolybdo- 
phosphate with Malachite Green. Analytica Chimica Acta, 211, 119-127. https://doi.org/10.1016/S0003-2670(00)83674-0

[25] Falade, K.O. and Akingbala, J.O. (2010) Utilization of Cassava for Food. Food Reviews International, 27, 51-83. https://doi.org/10.1080/87559129.2010.518296

[26] Fermont, A.M., van Asten, P.J.A., Tittonell, P., van Wijk, M.T. and Giller, K.E. (2009) Closing the Cassava Yield Gap: An Analysis from Smallholder Farms in East Africa. Field Crops Research, 112, 24-36. https://doi.org/10.1016/j.fcr.2009.01.009

[27] Jarvis, A., Ramirez-Villegas, J., Campo, B.V.H. and Navarro-Racines, C. (2012) Is Cassava the Answer to African Climate Change Adaptation? Tropical Plant Biology, 5, 9-29. https://doi.org/10.1007/s12042-012-9096-7

[28] Hauser, S. and Nolte, C. (2002) Biomass Production and N Fixation of Five Mucuna Pruriens Varieties and Their Effect on Maize Yields in the Forest Zone of Cameroon. Journal of Plant Nutrition and Soil Science, 165, 101-109. https://doi.org/10.1002/1522-2624(200202)165:1<101::AID-JPLN101>3.0.CO;2-F

[29] Yamoah, C.F. and Mayfield (1990) Herbaceous Legumes as Nutrient Sources and Cover Crops in the Rwandan Highlands. Biological Agriculture and Horticulture, 7, 1-15. https://eurekamag.com/research/007/395/007395422.php 